\title{
KEPUTUSAN PEMBELIAN PRODUK HALAL PADA GENERASI MUSLIM (GENM)
}

\author{
Nova Adhitya Ananda ${ }^{1},{ }^{2}$ Mikhratunnisa $^{2^{\star}}$ \\ ${ }^{1}$ Fakultas Ekonomi dan Bisnis Universitas Teknologi Sumbawa \\ ${ }^{2}$ Fakultas Teknologi Pertanian Universitas Teknologi Sumbawa \\ *Corresponding Author email:nova.adhitya.ananda@uts.ac.id, mikhratunnisa@uts.ac.id
}

\begin{tabular}{|c|c|}
\hline & Abstrak \\
\hline $\begin{array}{l}\text { Diterima } \\
\text { Bulan Juni } 2020\end{array}$ & $\begin{array}{l}\text { Generasi Muslim atau disingkat Gen M merupakan generasi muda Muslim yang percaya } \\
\text { akan iman dan modernitas. Perilaku pembelian Gen M sangat jarang diteliti sehingga } \\
\text { penulis tertarik untuk meneliti hal-hal yang dijadikan pertimbangan Gen M dalam } \\
\text { melakukan keputusan pembelian. Penelitian ini bertujuan untuk mengetahui perilaku Gen }\end{array}$ \\
\hline $\begin{array}{l}\text { Diterbitkan } \\
\text { Bulan Juli } 2020\end{array}$ & $\begin{array}{l}\text { M menggunakan pendekatan Theory of Planned Behavior (TPB). Variabel yang } \\
\text { digunakan antara lain adalah religiusitas, label halal, bahan produk, minat beli dan } \\
\text { keputusan Pembelian. Teknik analisis data yang digunakan dalam penelitian ini } \\
\text { menggunakan Structural Equation Modelling (SEM) dengan alternatif Partial Least }\end{array}$ \\
\hline Keyword : & Square (PLS). Jumlah responden sebanyak 200 responden. Hasil penelitian menunjukan \\
\hline Theory Planned & bahwa minat beli menjadi mediasi hubungan antara religiusitas, label halal, dan bahan \\
\hline Behavior, & produk terhadap keputusan pembelian. \\
\hline Keputusan & \\
\hline Pembelian & \\
\hline
\end{tabular}

\section{PENDAHULUAN}

Indonesia merupakan negara dengan jumlah penduduk yang besar. Jumlah penduduk Indonesia diperkirakan pada tahun 2019 sebanyak 267 juta jiwa (BPS, 2015). Dimana 87\% dari penduduknya beragama Islam (Katadata, 2019). Hal ini membuat Indonesia menjadi pasar potensial bagi produk asing. Hampir $90 \%$ barang yang dijual pada market place Indonesia merupakan buatan luar negeri (Kompasiana, 2020). Merek-merek asing tersebut menguasai hampir seluruh sektor di Indonesia termasuk sektor makanan dan minuman. Merek-merek tersebut berasal dari negara-negara yang penduduknya minoritas muslim sehingga kurang memperhatikan kehalalan produk seperti Inggris maupun Korea Selatan. Dikarenakan penduduk Indonesia sebagian besarnya adalah muslim membuat semua produk makanan yang diperdagangkan di Indonesia haruslah memiliki sertifikasi halal.

Sertifikat halal adalah suatu fatwa tertulis dari Majelis Ulama Indonesia (MUI) yang menerangkan kehalalan suatu produk sesuai dengan syariat Islam. Suatu produk baru mendapatkan ijin pencatuman label halal setelah mendapatkan sertifikat halal. Pada tahun 2017 lalu ada 11 produk makanan dari luar negeri yang belum memiliki label halal dari MUI padahal produk tersebut sangat laku dipasaran (Kompas, 2017). Hal ini menandakan bahwa masih banyaknya produk dari luar negeri yang dijual di Indonesia belum memiliki sertifikat halal dari Pemerintah Indonesia.
Pasar muslim di Indonesia sangatlah besar dan akan terus berkembang di tahun-tahun depan sehingga penting bagi sebuah produk untuk memiliki label halal. Besarnya pasar muslim ini tidak terlepas dari adanya segmen menengah muslim yang dikenal sebagai Generas Muslim (GenM). Generasi M adalah populasi muda muslim yang terus bertumbuh dan mereka percaya akan iman dan modernitas (Janmohamed, 2016). Kehalalan sebuah produk teruratama makanan dan minuman sangat mempengaruhi pembelian dari Gen M (Yuswohady, Irvan, Farid, \& Ali, 2017).

Gen $M$ memiliki pertimbangan tersendiri dalam mempertimbangkan sebuah produk. Faktorfaktor yang kemudian mempengaruhi perilaku (behavior) Gen $\mathrm{M}$ akan dijelaskan menggunakan Theory of Planned Behavior (TPB). Berdasarkan Theory of Planned Behavior, manusia berperilaku (behavior) dipengaruhi beberapa faktor seperti yang terlihat pada gambar 1 .

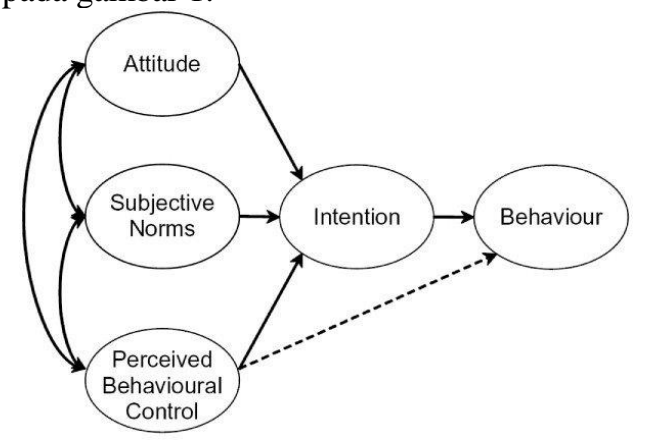


Gambar 1. Theory of Planned Behavior (Ajzen, 1991)

Perilaku (behavior) yang akan dibahas dalam penelitian ini tentang perilaku konsumen yang akan direpresentasikan melalui variabel Keputusan Pembelian. Keputusan pembelian (behavior) yang dilakukan oleh konsumen dalam membeli produk halal sangat penting untuk diteliti. Hal ini akan berdampak terhadap peningkatan penjualan perusahaan yang nantinya akan mendatangkan keuntungan bagi perusahaan (Kotler dan Amstrong, 2015)

Minat Beli dalam penelitian ini merupakan representasi dari Minat Berperilaku (intention). Minat beli berpengaruh signifikan terhadap keputusan pembelian (Restanti, Kusumawati, \& Devita, 2019). Minat beli merupakan kecendrungan konsumen terhadap suatu produk dimana konsumen tertarik dan berusaha mendapatkan produk tersebut. Minat beli dipengaruhi oleh variabel Religiusitas (Maharani \& Silvia, 2019) merupakan representasi dari attitude, Label Halal (Widyaningrum, 2019) representasi subjective norm dan Bahan Produk (Fauzia, Pangestuti, \& Bafadhal, 2019) representasi dari perceived behavioral control.

Salah satu produk halal yang menarik untuk diteliti yaitu mie samyang karena mie ini salah satu merek makanan asing yang sejak lama dijual di Indonesia dan sangat laku. Mie samyang merupakan produk makanan yang berasal dari Korea Selatan diproduksi oleh Samyang Foods Co,Ltd. Pada akhir tahun 2017, mie samyang sempat diisukan mengandung DNA spesifik babi (Kumparan, 2017). Berdasarkan hasil obsevasi awal peneliti di beberapa minmarket yang ada di Kabupaten Sumbawa menunjukan bahwa mie samyang merupakan salah satu produk mie yang sangat sering dibeli konsumen. Namun mie indomie yang merupakan merek asli Indonesia masih menjadi juara dibandingkan dengan mie samyang. Menarik untuk mengkaji lebih lanjut mengenai sikap Generasi Muslim (Gen-M) dalam membeli produk halal yang berasal dari negara yang minoritas muslim.

\section{LANDASAN TEORI}

\section{Theory of Planned Behavior (TPB)}

Ajzen (1991) mengembangkan Theory of Planned Behavior (TPB) yang sering digunakan dalam penelitian perilaku konsumen sebagai pendekatan untuk memprediksi Minat dan Perilaku. Dalam model tersebut juga dijelaskan bahwa Minat (intention) dipengaruhi oleh Subjective Norm, Attitude, dan perceived behavioral control.

Penelitian ini akan mengoperasional variabel Perilaku (behavior) menjadi Keputusan Pembelian, Minat (intention) menjadi variabel
Minat Beli, Subjective Norm menjadi Label Halal, Attitude menjadi Religiusitas, dan perceived behavioural control menjadi Bahan Produk.

Religiusitas merupakan kualitas penghayatan dan sikap hidup seseorang berdasarkan nilai-nilai agama yang diyakininya. Religiusitas didefinisikan sebagai sejauh mana seseorang dapat menerapkan nilai agama yang dianutnya kedalam sikap dan perilaku sehari-hari (Johnson, Jang, Larson, \& Li, 2001). Semakin tinggi religiusitas seseorang akan membuat mereka mencari produkproduk yang sesuai dengan nilai agama yang dianutnya. Maka minat beli terhadap produk-produk halal juga akan semakin meningkat (Zahri \& Hafasnuddin, 2016). Maka penelitian berhipotesis : H1 : Religiusitas berpengaruh terhadap Minat Beli.

Label halal pada kemasan produk hanya dapat dicantumkan ketika produk tersebut telah mendapatkan sertifikat halal dari MUI. Produk yang didaftarkan untuk uji kehalalannya akan dilakukan uji terkait dengan proses dan zat yang terkandung di dalam produk tersebut telah terhindar dari hal-hal yang dilarang oleh syariat Islam. Apabila terdapat suatu produk yang belum terdapat labelisasi halal, secara otomatis produk tersebut diragukan kehalalannya dan umat Islam dapat berhati-hati dalam membeli produk tersebut (Al-Asyhar, 2003). Label halal mempengaruhi minat beli konsumen (Hidayati \& Yuliandani, 2020)

H2 : Label Halal berpengaruh terhadap Minat Beli

Produk halal terlihat dari komposisi bahan yang digunakan. Bahan produk haruslah memiliki kandungan yang sesuai dengan syariat Islam. Bahan produk yang halal akan membuat konsumen berminat untuk membeli produk tersebut (Fauzia, Pangestuti, \& Bafadhal, 2019)

H3 : Bahan Produk berpengaruh terhadap Minat Beli

Minat beli merupakan faktor pendorong dalam pengambilan keputusan pembelian terhadap sebuah produk. Minat (interest) merupakan sebuah situasi dimana konsumen belum melakukan sebuah tindakan. Minat merupakan perilaku yang muncul sebagai respon terhadap suatu objek yang menunjukan keinginan pelanggan untuk melakukan pembelian (Kotler dan Keller, 2016) Ketika minat beli telah muncul maka akan memengaruhi seseorang untuk mengambil keputusan pembelian (Darmawan \& Prabawani, 2020).

H4 : Minat Beli berpengaruh terhadap Keputusan Pembelian

\section{METODE PENELITIAN}

\section{Populasi dan Sampel}

Populasi dalam penelitian ini adalah Generasi Muslim di Kecamatan Sumbawa yang 
pernah melakukan pembelian produk mie samyang. Teknik pengambilan sampel menggunakan purposive sampling dengan kriteria yaitu Gen-M (generasi muslim) berusia 24-28 tahun yang berdomisili di Kecamatan Sumbawa. Pernah membeli dan mengonsumsi produk mie samyang dalam 3 bulan terakhir. Jumlah sampel yang digunakan dalam penelitian ini sejumlah 200 responden.

\section{Definisi Operasional}

Definisi opersaional variabel merupakan suatu atribut atau sifat atau nilai dari objek yang memiliki variasi tertentu yang ditetapkan oleh peneliti untuk dipelajari dan kemudian ditarik kesimpulannya (Sugiyono, 2016). Dalam penelitian ini variabel religiusitas menggunakan indikator kepercayaan, ritual, ketaatan, pengalaman dan konsekuensi (El-Menouar, 2014).

Variabel label halal menggunakan indikator gambar, tulisan, kombinasi gambar dan tulisan, menempel pada kemasan. Variabel bahan produk menggunakan indikator keakraban bahan produk, infomasi tentang bahan-bahan pada produk sangat penting, terminologi kompleks yang digunakan dalam menjelaskan bahan produk sulit dipahami, bahan yang tidak familiar menimbulkan kecurigaan dalam hal halal, bahan produk menerminkan keamanan dan kualitas produk (Jamari, Samingin, \& Sundram, 2014).

Minat beli menggunakan indikator tertarik untuk mencari informasi, mempertimbangkan untuk membeli, tertarik untuk mencoba dan ingin memiliki produk (Schiffman \& Kanuk, 2008). Dan untuk variabel keputusan pembelian menggunakan indikator keputusan tentang merek, keputusan tentang kuantitas, keputusan tentang metode pembayaran, keputusan tentang waktu pembelian (Kotler \& Keller)

\section{Teknik Analisis Data}

Teknik ananlisis data yang digunakan dalam penelitian ini adalah menggunakan Structural Equation Modelling (SEM) dengan Partial Least Square (PLS). Adapun langkah pengujiannya adalah sebagai berikut (Ghozali, 2014) :

1. Merancang Inner Model

2. Merancang Outer Model

3. Evaluasi Model

4. Pengujian Hipotesis

\section{HASIL DAN PEMBAHASAN}

\section{Analisis Data}

1.Merancang Inner Model

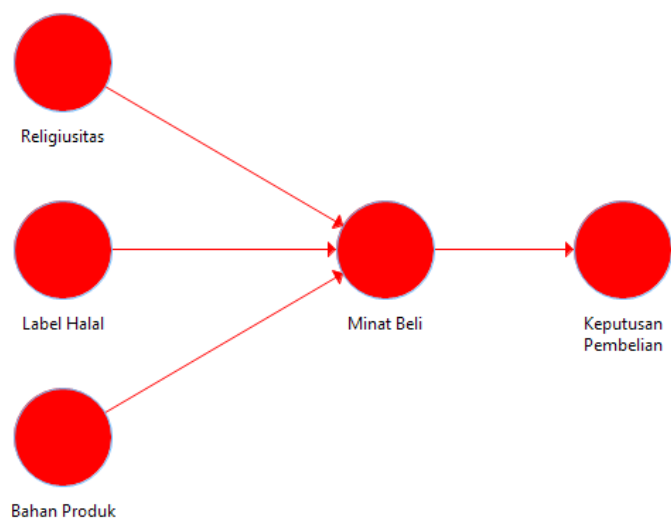

Gambar 2. Inner Model

\section{Merancang Outer Model}

Indikator yang digunakan dalam penelitian ini adladan indikator reflektif. Seperti pada gambar dibawah ini.

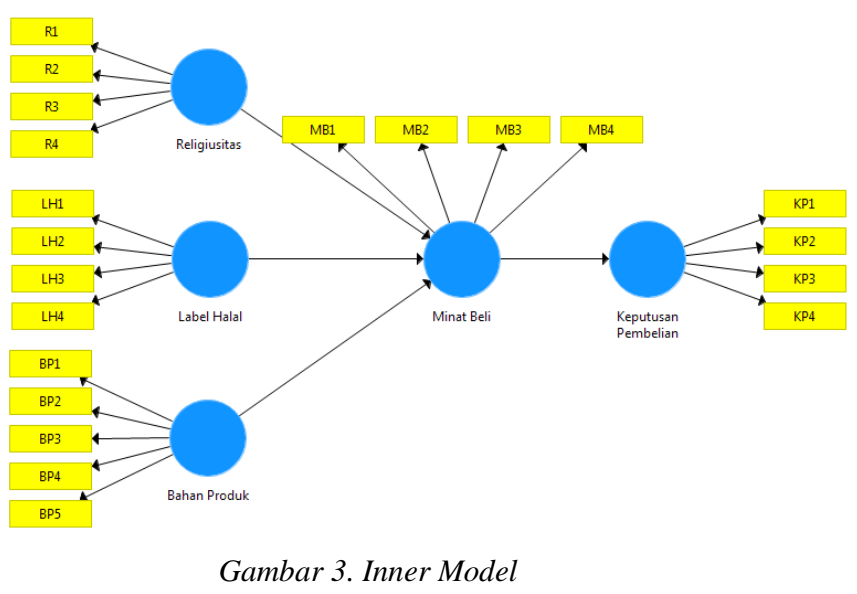

\section{Evaluasi Model}

Outer model adalah penilaian terhadap reliabilitas dan validitas variabel penelitian. Kriteria ukuran indikator reflektif yang baik adalah yang memiliki nilai korelasi convergent validity lebih dari 0,70 . Namun nilai 0,5 sampai dengan 0,6 masih dapat dipertahankan untuk model yang masih dalam tahap pengembangan (Chin, 1998).

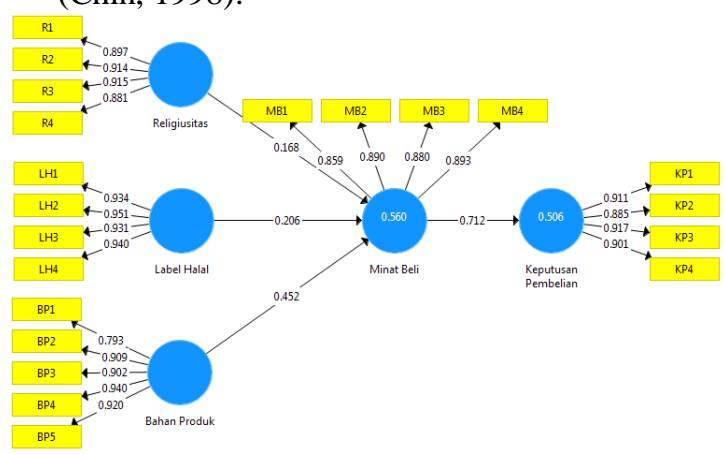


Adapun hasil discrimate validity pada model dapat dilihat pada nilai crossloading sebagai berikut :

Tabel 1. Discrimant Validity

\begin{tabular}{|l|c|c|c|c|c|}
\hline \multirow{2}{*}{$\begin{array}{c}\text { Indik } \\
\text { ator }\end{array}$} & \multicolumn{5}{|c|}{ Konstruk } \\
\cline { 2 - 6 } R1 & 0.897 & 0.664 & 0.672 & 0.625 & 0.608 \\
\hline R2 & 0.914 & 0.670 & 0.645 & 0.533 & 0.567 \\
\hline R3 & 0.915 & 0.714 & 0.664 & 0.586 & 0.629 \\
\hline R4 & 0.881 & 0.704 & 0.561 & 0.570 & 0.529 \\
\hline LH1 & 0.723 & 0.934 & 0.621 & 0.585 & 0.624 \\
\hline LH2 & 0.745 & 0.951 & 0.672 & 0.637 & 0.654 \\
\hline LH3 & 0.700 & 0.931 & 0.631 & 0.595 & 0.630 \\
\hline LH4 & 0.696 & 0.940 & 0.607 & 0.579 & 0.606 \\
\hline BP1 & 0.521 & 0.434 & 0.793 & 0.633 & 0.580 \\
\hline BP2 & 0.630 & 0.658 & 0.909 & 0.647 & 0.766 \\
\hline BP3 & 0.718 & 0.664 & 0.902 & 0.635 & 0.789 \\
\hline BP4 & 0.642 & 0.629 & 0.940 & 0.606 & 0.761 \\
\hline BP5 & 0.640 & 0.624 & 0.920 & 0.642 & 0.749 \\
\hline MB1 & 0.497 & 0.493 & 0.611 & 0.859 & 0.581 \\
\hline MB2 & 0.650 & 0.641 & 0.639 & 0.890 & 0.650 \\
\hline MB3 & 0.582 & 0.570 & 0.641 & 0.880 & 0.651 \\
\hline MB4 & 0.528 & 0.535 & 0.606 & 0.893 & 0.619 \\
\hline KP1 & 0.687 & 0.626 & 0.815 & 0.659 & 0.911 \\
\hline KP2 & 0.526 & 0.600 & 0.646 & 0.618 & 0.885 \\
\hline KP3 & 0.548 & 0.580 & 0.781 & 0.647 & 0.917 \\
\hline KP4 & 0.579 & 0.616 & 0.705 & 0.647 & 0.901 \\
\hline Sumberyyyyy & 0 & 0.9 & & \\
\hline
\end{tabular}

Sumber : data primer diolah, 2020

Berdasarkan tabel 1 diatas menunjukan bahwa indikator R1, R2, R3 dan R4 memiliki korelasi terhadap konstruk Religiusitas (R) yang lebih tinggi dibandingkan dengan korelasi terhadap konstruk Label Halal (LH), Bahan Produk (BP), Minat Beli (MB) dan Keputusan Pembelian (KP). Begitu pula dengan korelasi masing-masing konstruk lainnya dengan indikator lebih tinggi dibandingkan dengan korelasi indikator dengan konstruk lainnya

Metode lainnya untuk menilai discriminant validity dengan melihat nilai dari average variance extracted (AVE). Nilai AVE > 0,50 menunjukan bahwa konstruk dalam penelitian dinyatakan valid (Gana \& Broc, 2019).
Tabel 2. Average Variance Extracted (AVE)

\begin{tabular}{|l|c|c|}
\hline Konstruk & $\boldsymbol{A V E}$ & $\begin{array}{c}\text { Status } \boldsymbol{A V E} \\
\mathbf{> 0 , 5 0}\end{array}$ \\
\hline Religiusitas (R) & 0.813 & Valid \\
\hline Label Halal (LH) & 0.882 & Valid \\
\hline Bahan Produk (BP) & 0.800 & Valid \\
\hline Minat Beli (MB) & 0.775 & Valid \\
\hline Keputusan Pembelian & 0.817 & Valid \\
\hline
\end{tabular}

Sumber : data primer diolah, 2020

Selain menguji validitas konstruk, uji reliabiltas konstruk juga perlu dilakukan dengan melihat nilai composite reliability dan cronbach's alpha. Data memiliki reliabilitas yang baik jika nilai composite reliability dan cronbach's alpha lebih dari 0,70 (Ghozali, 2014). Hasilnya sebagai berikut :

Tabel 3. Uji Reliabilitas

\begin{tabular}{|l|c|c|c|}
\hline Konstruk & $\begin{array}{c}\text { Cronbach } \\
\text { Alpha }\end{array}$ & $\begin{array}{c}\text { Composite } \\
\text { Reliability }\end{array}$ & $\begin{array}{c}\text { Status } \\
\mathbf{> 0 , 7 0}\end{array}$ \\
\hline Religiusitas (R) & 0.923 & 0.946 & Reliabel \\
\hline Label Halal (LH) & 0.955 & 0.968 & Reliabel \\
\hline Bahan Produk (BP) & 0.936 & 0.952 & Reliabel \\
\hline Minat Beli (MB) & 0.903 & 0.932 & Reliabel \\
\hline $\begin{array}{l}\text { Keputusan Pembelian } \\
\text { (KP) }\end{array}$ & 0.925 & 0.947 & Reliabel \\
\hline
\end{tabular}

Sumber : data primer diolah, 2020

Setelah mengevaluasi outter model, selanjutnya mengevaluasi inner model. Model struktural yang memiliki nilai R-Squre > 0,67 model dinyatakan baik, R-Square $>0,33$ model dinyatakan moderat, dan R-Square > 0,19 model dinyatakan lemah (Ghozali, 2014).

Tabel 4. R-Square

\begin{tabular}{|l|c|c|}
\hline Konstruk & R-Square & Status \\
\hline Minat Beli (MB) & 0.553 & Moderat \\
\hline Keputusan Pembelian (KP) & 0.504 & Moderat \\
\hline
\end{tabular}

Sumber : data primer diolah, 2020

Relevansi prediksi (Q-Square) yang berfungsi untuk memvalidasi model. Hasil Q-square predictive relevance dapat dinyatakan baik jika nilainya > 0 memberikan bukti bahwa model memiliki relevansi prediksi, sedangkan nilai QSquare < 0 mengindikasikan bahwa model kurang memiliki relevansi prediksi. Besaran Q2 memiliki nilai dengan rentang $0<\mathrm{Q} 2<1$, dimana semakin mendekati 1 menunjukan model semakin baik. Dari tabel 4 diatas dapat dihitung 
Q-square predictive relevance untuk model penelitian ini, hasilnya sebagai berikut :

$$
\begin{aligned}
\mathrm{Q}^{2} & =1-\left(1-\mathrm{R}_{1}^{2}\right)\left(1-\mathrm{R}_{2}^{2}\right) \\
& =1-(1-0.553)(1-0.504) \\
& =1-(0.447)(0.496) \\
& =1-0.222 \\
& =0.778(77,8 \%)
\end{aligned}
$$

\section{Pengujian Hipotesis}

Statistik uji yang digunakan adalah $\mathrm{t}$ statisktik dengan nilai t tabel (signifikansi $5 \%$ ) = 1,972. Hipotesis penelitian terbukti signifikan jika nilai t statistik lebih besar dari 1,972. Berikut adalah hasilnya

Tabel 5. Pengaruh Langsung

\begin{tabular}{|l|c|c|c|}
\hline Konstruk & $\begin{array}{c}\text { Original } \\
\text { Sample }\end{array}$ & $\begin{array}{c}\boldsymbol{T} \\
\text { Statistics }\end{array}$ & $\begin{array}{c}\text { Status } \\
\text { T Statistik }> \\
\mathbf{1 , 9 7 2}\end{array}$ \\
\hline Religiusitas $\rightarrow$ Minat Beli & 0.168 & 2.215 & Signifikan \\
\hline Label Halal $\rightarrow$ Minat Beli & 0.206 & 2.571 & Signifikan \\
\hline $\begin{array}{l}\text { Bahan Produk } \rightarrow \text { Minat } \\
\text { Beli }\end{array}$ & 0.452 & 5.520 & Signifikan \\
\hline $\begin{array}{l}\text { Minat Beli } \rightarrow \text { Keputusan } \\
\text { Pembelian }\end{array}$ & 0.712 & 17.397 & Signifikan \\
\hline
\end{tabular}

Sumber : data primer diolah, 2020

Dari data tabel 5 tersebut dapat disimpulkan bahwa $\mathrm{H} 1, \mathrm{H} 2, \mathrm{H} 3$, dan $\mathrm{H} 4$ diterima. Dalam penelitian ini selain dari pengaruh langsung juga ada pengaruh tidak langsung. Untuk dapat mengetahui pengaruh tidak langsung digunakan uji sobel. Berikut adalah hasilnya :

Tabel 6. Pengaruh Tidak Langsung

\begin{tabular}{|l|l|c|}
\hline Mediating & \multicolumn{1}{|c|}{ Relationships } & $\begin{array}{c}\text { Sobel } \\
\text { Test }\end{array}$ \\
\hline $\begin{array}{l}\text { Minat Beli } \\
\text { (MB) }\end{array}$ & $\begin{array}{l}\text { Religiusitas } \rightarrow \\
\text { Keputusan Pembelian }\end{array}$ & 2.193 \\
\hline $\begin{array}{l}\text { Minat Beli } \\
\text { (MB) }\end{array}$ & $\begin{array}{l}\text { Label Halal } \rightarrow \\
\text { Keputusan Pembelian }\end{array}$ & 2.547 \\
\hline $\begin{array}{l}\text { Minat Beli } \\
\text { (MB) }\end{array}$ & $\begin{array}{l}\text { Bahan Produk } \rightarrow \\
\text { Keputusan Pembelian }\end{array}$ & 5.254 \\
\hline
\end{tabular}

Sumber : data primer diolah, 2020

Dari hasil perhitungan sobel test diatas mendapatkan nilai $\mathrm{z}>1,960$ dengan tingkat signifikansi $5 \%$ maka dapat dikatakan bahwa 1) Minat Beli (MB) merupakan variabel mediasi hubungan antara Religiusitas (R), Label Halal (LH) dan Bahan Produk (BP) terhadap Keputusan Pembelian (KP).

\section{Pembahasan}

Keputusan pembelian pada generasi Muslim (Gen M) dari hasil penelitian dipengaruhi oleh religiusitas, label halal dan bahan produk yang dimediasi oleh niat beli. Hasil penelitian menunjukan bahwa semakin tinggi nilai religiusitas konsumen maka mereka akan tertarik untuk membeli produk-produk yang halal dan tidak bertentangan dengan syariat Islam. Temuan ini sejalan dengan penelitian yang dilakukan Zahri dan Hafasnuddin (2016). Ketertarikan terhadap produk halal kemudian membuat konsumen membeli produk halal tersebut. Temuan ini sejalan dengan penelitian yang dilakukan oleh Darmawan dan Prabawani (2020).

Hasil penelitian juga menemukan bahwa produk yang memiliki label halal akan membuat generasi Muslim tertarik membeli produk tersebut. Label halal dari MUI menjadi tanda di produk bahwa produk tersebut telah tersertifikasi halal sehingga tidak adalagi keraguan akan kehalalan produk tersebut. Hasil ini sejalan dengan penelitian yang dilakukan oleh Hidayati dan Yuliandani (2020).

Temuan terakhir dalam penelitian menemukan bahwa bahan produk berpengaruh terhadap minat beli. Sejalan dengan hasil penelitian yang dilakukan oleh Fauzia, Pangestuti, dan Bafadhal (2020). Produk halal adalah produk yang kandungan didalam produk tersebut tidak mengandung bahan-bahan yang bertentangan dengan syariat Islam. Produk yang mengandung bahan yang sesuai dengan syariat Islam akan menarik generasi Muslim (Gen M) untuk membeli produk tersebut.

\section{KESIMPULAN}

Penelitian ini bertujuan untuk menganalisis keputusan pembelian pada Generasi Muslim (Gen M). Data didapatkan dari 200 responden yang memiliki umur antara 24-28 tahun. Hasil penelitian menunjukan bahwa Minat beli menjadi mediasi hubungan antara Religiusitas, Label Halal dan Bahan Produk terhadap Keputusan Pembelian.

Pada penelitian ini objek yang diteiti hanya terbatas pada Generasi Muslim di Kecamatan Sumbawa. Untuk penelitian selanjutnya agar membandingkan keputusan pembelian di tiap generasi.

\section{REFERENSI}

Ajzen, I. (1991). The theory of planned behavior. Organizational Behavior and Human Decision Processes , 50 (2), 179-211.

Al-Asyhar, T. (2003). Bahaya Makanan Haram bagi Kesehatan Jasmani dan Kesucian Rohani. Jakarta: PT. AL-Mawardi Prima. 
BPS. (2015). Profil Penduduk Indonesia Hasil. Jakarta: Badan Pusat Statistik.

Chin, W. W. (1998). The Partial Least Square Approach to Strutural Equation Modelling. Modern Methods For Business Research, Hal. 295-336.

Darmawan, A., \& Prabawani, B. (2020). Pengaruh Promosi dan Persepsi Nilai Terhadap Keputusan Pembelian Melalu Mina Beli Sebagai Variabel Intervening. Jurnal Ilmu Administrasi Bisnis, Vol. 9, No.2, Hal. 96105.

El-Menouar, Y. (2014). The five dimensions of Muslim religiosity. Results of an empirical study. Methods, Data, Analyses 8.1, 26.

Fauzia, D. R., Pangestuti, E., \& Bafadhal, A. S. (2019). Pengaruh Religiusitas, Sertifikasi Halal, Bahan Produk Terhadap Minat Beli dan Keputusan Pembelian. Jurnal Administrasi Bisnis (JAB), Vol. 66, No. 1, Hal 37-46.

Gana, K., \& Broc, G. (2019). Structural Equation Modelling With Lavaan. Hoboken: John Willey \& Sons, Inc.

Ghozali, I. (2014). Structural Equation Modelling (SEM) Metode Alternatif dengan Partial Least Square (PLS). Semarang: Universitas Diponegoro Press.

Hidayati, N., \& Yuliandani, L. (2020). Pengaruh Beauty Vlogger, Citra Merek dan Label Halal Terhadap Minat Beli Produk Kosmetik Wardah. JSMA : Jurnal Sains Manajemen dan Akuntansi, Hal. 66-76.

Jamari, M. F., Samingin, S. N., \& Sundram, V. P. (2014). Muslim's Purhase Intention Towards Non Muslim's Halal Packaged Food Manufacturer. SSRN.

Janmohamed, S. (2016). Generation M : Young Muslims Changing the World. New York: Bloomsbury Publishing PLC.

Johnson, B. R., Jang, S. J., Larson, D. B., \& Li, S. D. (2001). Does Adolescent Religious Commitment Matter? A Reexamination of the Effects of Religiosity on Delinquency. Journal of Research in Crime and Delinquency, Vol. 38 (1), Hal. 22-34.
Kotler, P., \& Amstrong, G. (2015). Prinsip-prinsip Pemasaran. Jakarta: Erlangga.

Kotler, P., \& Keller, K. L. (2016). Manajemen Pemasaran Edisi 13 Jilid 1. Jakarta: Erlangga.

Maharani, N. K., \& Silvia, A. (2019). Analisis Pengaruh Pengetahuan dan Religiusitas terhadap Niat Pembelian Produk Kosmetik Halal. AL-URBAN : Jurnal Ekonomi Syariah dan Filantropi Islam, Vol. 3, No.1, Hal. 81-94.

Restanti, F. A., Kusumawati, A., \& Devita, L. D. (2019). Pengaruh Celebrity Endorser dan Electronic Word of Mouth Terhadap Minat Beli dan Dampaknya Terhadap Keputusan Pembelian. Jurnal Administrasi Bisnis (JAB), 68, Hal. 28-37.

Schiffman, L., \& Kanuk, L. L. (2008). Perilaku Konsumen. Jakarta: Indeks.

Sugiyono. (2016). Metode Penelitian Kuantitatif, Kualitatif dan $R \& D$. Bandung: Alfabeta.

Widyaningrum, P. W. (2019). Pengaruh Label Halal, Kesadaran Halal, Iklan, dan Celebrity Endorser terhadap Minat Pembelian Kosmetik Melalui Variabel Persepsi Sebagai Mediasi. CAPITAL : Jurnal Ekonomi dan Manajemen, Vol. 2, Nomor 2, Hal. 75-97.

Yuswohady, H., Irvan, F., Farid, \& Ali, H. (2017). Gen M\# Generation Muslim "Islam itu Keren". Bandung: Mizan Media Utama.

Zahri, Y., \& Hafasnuddin. (2016). Pengaruh Religiusitas terhadap Minat Beli Produk/Jasa Bank Syariah dengan Sikap Konsumen sebagai Variabel Mediasi. Jurnal Ilmiah Mahasiswa Ekonomi Manajemen, Vol.1, No.1, Hal. 75-91.

\section{Internet}

Katadata. (2019). Indonesia negara dengan jumlah penduduk muslim terbesar dunia. http://databoks.katadata.co.id. Diakses pada 10 Juli 2020. 10:00 WITA.

Kompas. (2017). Indonesia Halal Watch 11 produk makanan impor tidak berlabel halal. http://ekonomi.kompas.com. Diakses pada 11 Juli 2020. 07:00 WITA. 
SPECIAL ISSUE

JURNAL TAMBORA VOL. 4 NO. 2A JULI 2020

http://jurnal.uts.ac.id

Sacial Humaniara

Kompasiana. (2020). Upaya Indonesia melawan gempuran produk asing kaum kapitalis. http//kompasiana.com. diakses pada 10 Juli 2020. 11:00 WITA
Kumparan. (2017). Mie Samyang haram : semua yang perlu anda tahu.

http//kumparan.com. diakses pada $10 \mathrm{Juli}$ 2020. 09:00 WITA 